This is a pre-publication (but up-to-date) version of a review that has been published online at the British Journal of Sociology: http://doi.org/10.1111/1468-4446.12844. If you cite this paper,

please use the official published version.

\title{
Rule of Metrics
}

\author{
Shreeharsh Kelkar \\ Undergraduate and Interdisciplinary Studies (UGIS) \\ University of California, Berkeley \\ skelkar@berkeley.edu
}

Book under review:

Christin, Angèle. Metrics at work: Journalism and the contested meaning of algorithms. Princeton University Press, 2020.

In Metrics at Work: Journalism and the Contested Meaning of Algorithms, an ethnographic study of newsrooms, Angèle Christin walks the fine line between utopian and dystopian analyses of technology with a kind of rigorous empiricism. In these newsrooms, Christin finds web journalists using algorithmically mediated metrics (or "analytics") that document "the preferences of their readers, the popularity of their articles, and the reactions of their followers" (pxiii). The book demonstrates conclusively that these analytics have had far-reaching impacts on how newsrooms operate but these may not be what we commonly assume: analytics software did not lead journalists to maximize their clicks by producing more standardized material for the lowest common denominator. Instead, journalists responded in complex ways, drawing on their traditions and craft to balance their conflicting goals, such as seeking approval from their audiences and peers, and producing "good" journalism while also making a living wage. Christin labels these conflicts as arising from journalists" "click-based" versus "editorial" modes of evaluation. The metrics were thus symbols through which journalists debated and constructed their "algorithmic publics"; they inspired debate on what journalism was, who it was for, and what its relationship to other institutions of society might be.

Christin conducted ethnographic research at two publications, The Notebook in New York and LaPlace in Paris. (Readers will have fun figuring out the real names of these publications and the various characters but Christin wisely tells us early on to "try to forget those names as much as possible.") In Chapter 2, "Utopian Beginnings," Christin describes the trajectories of the two publications. The Notebook began as a native online magazine in the late 1990s, founded by a prominent print and TV journalist, and backed by a wealthy tech company. It experimented with various forms of online-only journalism: building forums for reader feedback as well as publishing continuously (rather than weekly or monthly) and in new formats (e.g. epistolatory book clubs). La Place was inspired by the success of The Notebook but its organization was more fluid. Unlike the American publication which was organized hierarchically just like a 
regular American newsroom, work roles at LaPlace were blurry, self-consciously countercultural, and many employees were not paid at all. LaPlace was also more explicitly political, grounded in the French tradition of journalists as intellectuals, than The Notebook which was grounded in American ideals of non-partisan, "objective," journalism that informed, rather than guided, public opinion.

By the late 2000s, both publications had been forced to enter the "chase for clicks" (Chap 3) as they had to compete with even more web-savvy upstarts, work with social media platforms like Google and Facebook which had become outsized conduits for distributing the news, and deal with the effects of the sluggish online advertising market. They dealt with this by increasing the frequency at which they published, and by aggressively using metrics for "traffic maximization" to secure revenue. At both publications, journalists experienced a struggle between two alternative schemes to evaluate the worth of their work: "click-based" versus "editorial," indexing the approval of their audiences and peers, respectively. When operating in the editorial mode, they placed a priority on original reporting, long-form writing, and approval of other journalists (through awards and such), while in the click-based mode, they focused on engaging with their audiences, short-form writing, and "going viral."

At this point, however, their paths diverged and the American and French journalists drew on metrics differently (Chap 4: "The Multiple Meanings of Clicks"). At The Notebook, there was a sharp disjuncture between how the editors and the writers viewed metrics. Editors used metrics to make editorial decisions about which issues the magazine should focus on and they encouraged writers to keep track of these metrics, regularly sending out updates on how particular articles were doing - which the writers resisted as much as possible. At LaPlace, where the distinction between editors and writers was blurry in practice, both groups engaged with metrics with ambivalent feelings, seeing them as crassly commercial but also somewhat "magical" (p99) in that they allowed journalists to feel the pulse of their readers. Christin argues that this difference is not just superficial, that indeed, the two groups "did not see the same things when they looked at metrics" (emphasis in the original, p96). At The Notebook, American journalists, shaped in a culture of autonomous high-minded informational journalism, saw in metrics a form of commercialism that they had been trained to be suspicious of. They interpreted the metrics with the same conflicted feelings they had for their readers. The French journalists at LaPlace saw the metrics as a way of engaging and shaping public opinion. And yet, when LaPlace was ultimately sold to a different owner who asked the French journalists to pay more attention to audience metrics, they balked. Their resistance however was based less on some notion of journalistic autonomy but on the "authentic and civic nature" (p100) of their relationship with their readers which the metrics presumably corrupted.

In Chap 5, Christin turns to the effect of metrics on time in the newsroom. Publishing online means that the news can be updated constantly at a trivial cost. Both publications had been pushed by financial considerations to put out more content but their approach to this content was again refracted through their organizational routines. Negotiating the tension between the clickbased and editorial modes of evaluation, editors at The Notebook put different writers in charge of the "fast" (e.g. quick response to a current event) and "slow" (e.g. investigative) pieces, and 
strove to balance them. Editors almost always ended up giving the top spots on their websites to the slow articles; the slow writers mostly had disdain for the fast articles. At LaPlace, there was no such distinction between fast and slow writers, and everyone (even the editors) wrote different kinds of articles based on what was required. The overall procedure for deciding headlines for where the articles should go on the website was informal and articles that took the best spot on the homepage were just as likely to be original articles as pieces written by nonjournalists ("academics, activists, experts, or politicians" or even just regular people).

The final chapter discusses how all these dynamics mapped to the question of compensation and career strategies for journalists. At both publications, editors were more likely to evaluate freelance writers through the click-based mode of evaluation than regular staff. At The Notebook, freelance writers were paid considerably lower salaries than they would have in earlier days. Moreover, salaries were an opaque topic, negotiated between writers and editors, where editors had considerable discretion to set a wide range of salaries. At LaPlace, freelance writers were often paid a (low) flat salary (with ad hoc exceptions). LaPlace also relied to a greater degree on the labor of unpaid contributors, who were described, through conscious boundary work, as nonjournalists. Both the American and French freelance writers drew on metrics to construct themselves as entrepreneurial subjects despite the attendant hardships, with the Americans being more upbeat and the French more ambiguous.

I have some quibbles with the book. In Chap 4, Christin argues, drawing on the historian Theodore Porter's history of cost-benefit analysis, that American editors' use of metrics to manage their employees indicates a "trust in numbers" (p82). But Porter's point was that it was weak experts, hemmed in on all sides by many powerful political interest groups, who turned to numbers to burnish the trust that was placed in them. Similarly, the American editors' projection of "strong values and beliefs about rationality and objectivity unto these quantitative tools" (p83) may be more a sign of their relative weakness as they are forced into a corner by the publication's financial bottom-line and their writers' strong preference for autonomysomething I wish the book had delved into more. In Chap 5, the metrics recede into the background somewhat and the focus shifts to organizational culture. While the distinction that Christin makes between The Notebook's bureaucratic" mode of organization versus LaPlace's "disciplinary" one is well-taken, I wanted to know more about how the metrics affected journalists' experience of time itself and the rhythm of their work life (on which, see Dominic Boyer's The Life Informatic).

But these are quibbles. Metrics at Work is a studiously detailed book that takes a rigorously empirical approach to its material. Along with Sarah Brayne's recent book on police analytics (Predict and Surveil), it demonstrates that high-status workers can carve out a space of autonomy where they can use their expert discretion to interpret metrics: the metrics do not rule them. Lowstatus workers (like freelance journalists), on the other hand, seem to be caught in a vortex where their lower institutional position makes them more and more susceptible to the rule of metrics, diminishing their autonomy even further (see Gray and Suri's Ghost Work). The research demonstrates conclusively that we need more activism to secure labor rights and protections for workers in general and low-status workers in particular. 